\title{
THE LEGAL CAPACITY IN CONTRACT FOR MEDICAL TREATMENT (THE COMPARATIVE STUDY BETWEEN INDONESIAN LAW, DUTCH LAW, AND ENGLISH LAW)
}

\author{
Sri Ratna Suminara, Yoni Fuadah Syukriani ${ }^{b}$, U. Sudjanac, Efa Laela Fakhriah ${ }^{d}$
}

\begin{abstract}
This article aims to determine the criterion of legal capacity of a patient in a contract for medical treatment and the legal consequences of a contract for medical treatment made by a minor. This article uses a normative juridical research method with a law approach and the data sources used are obtained from literature studies and document studies, and study results showed that there is a similar criterion for determining whether a patient is competent or not in giving consent for medical treatment between Indonesian law and Dutch law that is based on a legally fixed age. However, based on Dutch law, the age of legal capacity to consent for medical treatment differs from the age of legal majority. Meanwhile, English law uses mixed approaches to determine a minor capacity in giving consent for medical treatment that is based on the age and competence of a minor. Furthermore, according to Indonesian Law, a contract for medical treatment made by minors is voidable, whereas according to Dutch Law and also English Law any contract for medical treatment made by minors is legally binding.
\end{abstract}

Keywords: contract for medical treatment; legal capacity; legal comparative study.

\footnotetext{
a Fakultas Hukum Universitas Islam Bandung, Jl. Ranggagading No. 8, Tamansari Bandung 40116, email: sriratnasuminar@yahoo.com.

b Fakultas Kedokteran Universitas Padjadjaran, Jalan Raya Bandung-Sumedang KM. 21 Jatinangor 45363, email: yoni.fuadah@unpad.ac.id.

c Fakultas Hukum Universitas Padjadjaran, Jalan Raya Bandung-Sumedang KM. 21 Jatinangor 45363, email: sudjana@unpad.ac.id.

d Fakultas Hukum Universitas Padjadjaran, Jalan Raya Bandung-Sumedang KM. 21 Jatinangor 45363, email: efa@unpad.ac.id.
} 


\section{INTRODUCTION}

In Indonesia, one of the most important thing in a contract is capacity, as capacity is one of element required to establish a contract. And the easiest way to assess someone competent in making a contract by looking at his age. Therefore, in the eyes of Indonesian law, age is very important because it relates to a person's capacity to do legal actions. Because the discussion about age is very important, then in Indonesia the limit of the age of majority is governed by various laws and regulations according to the field of life, so no wonder the limit of the age of majority very diverse in Indonesia. Nevertheless, the diversity of the limit of age majority leads to the problem, especially for a contract in the field of medical services because in this field the age of majority has not been stipulated clearly by the legislation in Indonesia, thus it leads us to the question: what is a limit of the age of majority recognized in the field of medical service? which the limit of the age of majority should be used in the field of medical service? And which of regulations should be obeyed to determine the age of majority in the field of medical service?

The answer to the question about the age of the majority above is very necessary especially for the parties who will make a contract for medical treatment, it can be used as consideration for whether or not a patient is legally competent to make a contract for medical treatment. However, the problem here, the contract in the field of medical services has different characteristics from other contracts. Besides, there is the international recognition of individual human rights that has an impact on the position of a minor. These rights include the right to life, the right to personal integrity, and the right to privacy. Their implementation is not dependent on the age of a person. This implies that a child may have gradually extensive rights to self-determination on the subject such as his privacy and consent with treatment in the light of his physical and mental integrity.

Based on international recognition as mentioned above, this means that minors can enter into a contract for medical treatment. However, is it possible for Indonesia to implement it? How can a minor be considered as a competent person to enter into a contract for medical treatment? The questions mentioned above are a challenge to Indonesian Law and therefore it must be answered. This issue needs to be addressed in order to give clarity and certainty to the law that can be used as a basis in medical practice. To that end, this paper aims to determine the criterion for determining that a person has capacity in a contract for medical treatment by comparing among Indonesian Law, Dutch Law, and English Law and to determine the legal consequences if the contract for medical treatment made by a minor. 
In this paper, Indonesian law will be compared with the Dutch law because Indonesia has the same legal system as the Netherland that is Civil Law System so that it has the same characteristic conceptual mindset (approach) regarding law such as law must first exist as a basis for resolving a legal problem. Besides, comparisons will be done with English law which adheres to the Common Law system in which solving legal issues from case to case. Why is it compared by English law? It is hoped that from the two extreme systems there are useful modifications that can be applied in Indonesia. Therefore, it does not intend to follow the rules of the English Law System automatically or to carry out legal transplants derived from English Law without reason. However, by comparing the two systems it will be known which one foreign or international rule is good or acceptable, and which rule should not be accepted into our national legal system.

Judging from its form, this research is normative juridical research with legal comparative approach that is research to investigate and compare law regarding legal capacity in a contract for medical treatment in the perspective of Indonesian Law, Dutch Law, and English Law. Concerning what mentioned above, the main focus of the study in this paper is to identify the differences and similarities regarding the criterion of legal capacity of patient in contract for medical treatment and legal consequences of a contract for medical treatment made by minor in the selected countries. Judging from the typology, this study is categorized as descriptive and comparative study. This paper describes the differences and similarities the criteria for determining whether or not someone can make a contract for medical treatment in the selected countries. Data were gathered from internet search and library resources, data analysis was done using comparative and qualitative method.

\section{DISCUSSION}

The Criterion of Legal Capacity for Medical Treatment in The Perspective of Indonesian Law, Dutch Law, and English Law

Before the criterion of legal capacity for medical treatment in the selected countries is analyzed, it is important to examine the concept of comparative study first. In legal science literature, the term legal comparison shows two different meanings. First, legal comparison as a legal study method; second, the comparison of law as a science. ${ }^{1}$ Comparison of law as a method is one way of conducting research or scientific study to obtain knowledge about law. ${ }^{2}$ In the comparison of law, the contents and forms of legal systems are compared to find and explain the similarities and differences and explain the factors that cause it and the possible direction of its development.

\footnotetext{
${ }^{1}$ Sri Warjiyati, Memahami dasar ilmu hukum: Konsep dasar ilmu hukum, edisi pertama, Prenadamedia Group Jakarta: 2018, p.125.

2 Sri Warjiyati, ibid., p.127.
} 
As a method, a legal comparison is considered as a way to study the law comprehensively by examining the legal system, rules, institutions, and history of more than one country or more than one legal system, although they are still valid in one country. ${ }^{3}$ As a result of the development of the modern era that raises needs that are different from the needs of the past, the existence of these new needs requires an inquiry into how other countries meet the needs of this modern age. That is why this paper uses the method of comparative law to study the laws that apply in other modern countries so that Indonesia can draw up its modern laws without compromising Indonesia's national interests and by not setting aside the morals and personalities of the Indonesian people.

Furthermore, to discuss the criterion of legal capacity for medical treatment, it is important to examine the age of majority and competence first, because both of them closely related to the legal capacity. What is the meaning of the age of majority? The age of majority is the age that children become adults by law. This means that they are legally in control over their actions and decisions, and their parents are no longer responsible for them. The opposite is a minority, which means being a minor or a child. The age of majority is a legally fixed age and the idea of adulthood which is different in different places.

The great dictionary of Indonesian language defines the age of majority (adult) in several senses, namely: (1). Until age; akilbalig (not children or teenagers anymore); (2). Has reached sexual maturity; (3). Mature (about thoughts, views, etc.). ${ }^{4}$ In the eyes of the Indonesian law, the limit age of majority is important because it relates to whether the person allowed to do a legal action, or treated as a legal subject, ${ }^{5}$ or determine whether or not a person valid to do legal action, ${ }^{6}$ and also the age of majority contains elements related to whether or not someone is accountable for legal actions that have been done, which describe the ability of someone to act especially in the field of civil. ${ }^{7}$ In addition, the limit age of majority is also applied when someone enters into a contract. ${ }^{8}$

In Indonesia, the age of majority is regulated in a variety of laws and regulations. [1] It can be seen from several laws that define the limit of the age of majority in various ways. Here are the limits of the age of majority according to several laws: [2] a). Article 330 of the Civil Code stipulates that the age of majority is 21 years old; b). Article 9 (1) Compilation of Islamic Law stipulates the age of

\footnotetext{
3 Munir Fuady, Perbandingan Hukum Perdata, Citra Aditya Bakti, Bandung: 2005, p. 3.

4 Nurkholis, "Penetapan Usia Dewasa Cakap Hukum Berdasarkan Undang-Undang dan Hukum Islam", <Journal.stainkudus.ac.id/index.php/Yudisial/article/download/3223/2346>, [accessed on 25/03/2019], p.76.

5 Irmadevita.com, "Batas Usia Dewasa”, <https://irmadevita.com/2008/batas-usia-dewasa/>, [accessed on 25/03/2019], p.1.

6 Agustinus Danan Suka Dharma, "Keberagaman Pengaturan Batas Usia Dewasa Seseorang untuk Melakukan Perbuatan Hukum dalam PeraturanPerundang-Undangan di Indonesia", <https://media.neliti.com/media/publications/213158-keberagaman-pengaturan-batasusia-dewasa.pdf>, [accessed on 25/03/2019], p.169.

7 Wahyono Darmabrata, "Usia Dewasa dalam Undang-Undang No. 1 Tahun 1974 Tentang Perkawinan", <file:///c:/Documents\%20\%settings/User/My\%Documents/Downloads/1406-2740-1-SM\%20(1).pdf>, [accessed on 25/03/2019], p.300

8 Agustinus Danan Suka Dharma, Op.Cit. (Note 10), p.169.
} 
majority is 21 years old; c). Article 47 (1) of Law Number 1 Year 1974 concerning Marriage stipulates age majority is 18 years old; d). Article 1 (1) of Law Number 23 of 2002 concerning Child Protection stipulates the age of majority is 18 years old; e). Article 7 of Law Number 23 of 2003 concerning Elections stipulates the age of majority is 17 years.

According to several legal provisions and regulations above, hence there is a lack of uniformity regarding the limit of the age of majority of a person so that it creates obscurity and confusion in determining at what age a person is declared capable of carrying out legal action. There are regulations that provide a limit of age majority of 21 (twenty-one) years of age, 18 years of age, some even give a limit of the age of majority of 17 (seventeen) years of age. Based on the diversity of regulations regarding the limit of the age of majority, the Indonesian government has made several efforts to uniform regulations so that there is no confusion in determining which rules must be obeyed and must be used. ${ }^{9}$

The effort to overcome the diversity of age majority regulations in carrying out legal actions is that the publication of two circular letters. First, the issuance of Circular Letter Number 7 of 2012 concerning the Legal Formulation of the Results of the Plenary Meeting of the Supreme Court as a Guide to Implementing Duties for the Court. The Supreme Court Circular, it has explained the provisions on the limits age of majority. It was stated in the Results of the Civil Chamber Meeting on March 14-16, 2012, that an adult is capable of acting in law, namely a person who has reached 18 years of age or has been married. Second, the issuance of the Circular of the Minister of Agrarian Affairs and Spatial Planning/Head of the National Land Agency Number 4/SE/I/2015 Regarding the Limitation of Adult Age in the Context of Land Services. In the provision of number 7, it is stated that the age of an adult who can perform legal actions in the framework of land services is at least 18 years old or has been married. ${ }^{10}$ Thus, the existence of these two efforts determines that limit of the age of majority is 18 years removing doubts and ambiguities regarding the limit of the age of majority in carrying out legal acts in Indonesia.

In Netherland, under the Dutch Law (Dutch Civil Code/Burgerlijk Wetboek), persons under the age of 18 years are considered minors, so from 18 years, people are considered adults. ${ }^{11}$ Meanwhile in English Law (at common law) at first-time persons under the age of 21 were designated 'infant' and had only a limited capacity to contract. From January 1, 1970, the Family Law Reform Act 1969 reduced the age of majority to 18 and authorized the term 'minor' as an alternative to 'infant'. Minor is now the preferred term. ${ }^{12}$ In English Law, once a person reaches the age of 18, he or she is no

\footnotetext{
9 Agustinus Danan Suka Dharma, Op.Cit. (Note 10), p.174.

${ }^{10}$ Agustinus Danan Suka Dharma, ibid., p.169.

${ }^{11}$ Embassy kingdom of the Netherlands, "Protection of Minors", www.protection-of minors.eu/en/country/NL, [accessed on 20/05/2019].

${ }^{12}$ NN, "Capacity Law Lecture, extract from JC Smith, Smith \&Thomas: A Casebook on Contract, Eleventh Edition", 2000, chapter 17, <https://www.lawteacher.net/lecture-notes/capacity-lecture.php>, [ accessed on 25/03/2019], p.2.
} 
longer a minor, he/she become an adult and, as a young adult, has the right and responsibility to make certain legal choices that adults make. Once a person reaches the age of majority, there are some things they can do that they could not do before. It may include entering into a contract at law.

Associated with the health care sector, it raises a question, is age as a benchmark or criterion for determining someone has capacity to consent for medical treatment? At the beginning of this paper, it is mentioned that there is the international recognition of individual human rights to the minor, and it has an impact on the position minor. The position of the minor has gradually changed over the years. A child may have gradually extensive rights to self-determination on subjects such as consent with treatment in the light of his physical and mental integrity. However, if a minor has a right to self-determination to provide consent for medical treatment what is the criterion which can be used as a benchmark to determine a patient has the capacity to provide consent for medical treatment? Legal dogma holds that no medical procedure can be performed without the patient's consent. The legal doctrine protecting the right of each individual to be touched only when and in the way authorized by that individual.

One of the first principles of medical Law is that a competent adult patient must give her consent to medical treatment. As Cardozo J famously said in the US case, Schloendorff v New York Hospital: ${ }^{13}$

"Every human being of adult years and sound mind has a right to determine what shall be done with his own body, and a surgeon who performs an operation without his patient's consent commits an assault."

The need for consent to treatment underlies two separate legal questions. The first relates to the practitioner's liability for battery if valid consent is not obtained. The second concerns the practitioner's right to compensation for services that have been authorized by someone with the legal capacity to make a binding contract.

According to the explanation above, hence every patient as an individual has a choice whether or not to undergo a proposed procedure, surgery, examination, or treatment. ${ }^{14}$ Therefore, obtaining a patient's consent is an important component of good medical practice, and also carries specific legal requirements to do so. ${ }^{15} \mathrm{~A}$ doctor can treat his patient only when consent is deemed legally valid under the eyes of the law in order to justify any medical treatment or procedure that a patient requires. ${ }^{16}$

\footnotetext{
${ }^{13}$ Emily Jackson, Medical Law, OXFORD University Press, New York: second edition, 2010, p.216.

${ }^{14}$ Malaysian Medical Council Guideline, "Consent for treatment of patients by registered medical practitioners", $<$ medicalprac.moh.gov.my>, [accessed on 23/03/2019], p.1.

${ }^{15}$ Malaysian Medical Council Guideline, Ibid., p.1.

${ }^{16}$ Tengku Noor azira Tengku Zainudin, at.All. , "The Meaning of a Valid Consent to Medical Treatment in Malaysia: Tan Ah Kau v Government of Malaysia Revisited.", <www.pertanika.upm.edu.my>, [accessed on 23/03/2019], p.35.
} 
Then, how about a minor? is a minor deemed as legal capacity to provide consent for medical treatment? Legal framework adopt various approaches to determine the extent to which minors are legally capable to consent to health care and to make their own health-care decisions. These approaches are dictated by law. There are three different approaches, namely: (i) consent by minors for health-care decisions from a fixed age onwards; (ii) competence assessment-based consent; (iii) a mixed approach where fixed age limits are combined with competence-based approaches. ${ }^{17}$

Under a legally fixed age approach, minors are presumed to be competent to give consent to medical treatment at the legally fixed age. Some countries use a fixed age approach, however with additional conditions or exceptions, from this approach, consent from minors should be sought, together with the consent of the parent (or legal representative). In certain countries, the law refers solely to a competency-based approach to evaluate the capacity of children to consent to medical interventions regardless of their age.

In Indonesia, there is a provision stipulating that there must be consent from the patient before the doctor provides medical treatment. It is stipulated in Article 45 (1) of Law Number 29 of 2004 concerning Medical Practice, which states that: "Every medical/dentistry treatment that the doctor/dentist is going to take for the sake of patient should be under the consent." However, the question is how to determine whether a patient has capacity to provide consent for medical treatment so that his consent is legally valid? Is the criterion seen only from the age of majority or from other factors?

Article 13 (1) and (2) Regulation of The Minister of Health of The Republic of Indonesia Number 290/MoH/PER/III/ Year 2008 Concerning Approval of Medical Action, state that:

1. Approval is given by a

competent patient or closest

family;

2. Assessment of patient competency as referred to in paragraph (1) can be carried out by a doctor or dentist before medical action is taken.

In Article 1 number 7 Regulation of The Minister of Health of The Republic of Indonesia Number 290/MoH/PER/III/ Year 2008 Concerning Approval of Medical Action, stated that:

"Competent Patients are adult or non-child patients according to legislation or have been/have been married, have not been disturbed by their physical awareness, can communicate naturally, have no mental retardation and do not experience mental illness so they can make free decisions. "

\footnotetext{
${ }^{17}$ Karine Senecal, at.all., "Legal Approaches Regarding Health-Care Decisions Involving Minors: Implications for Next-Generation Sequencing", 2016, E-Journal on-line, < https:www.ncbi.nlm.nih.gov/pmc/articles/PMC5110060/>, [accessed on 10/05/2020].
} 
In the provisions above, the capacity of a patient in providing consent is determined based on the age of majority. Therefore, a patient will be deemed as legally capacity to provide consent for medical treatment if he at age of majority. Although in the regulation of the minister of health above it is determined that consent must be given by competent patients. However, because in the following article stated that the meaning of competent is age of majority, so it can be concluded that in this regulation competent refer to age of majority. Thus, Indonesia uses a legally fixed age approach to presume that minor is competent to give consent for medical treatment. Therefore, the fixed age of capacity to consent for medical treatment is set at a similar age to the age of legal majority, which is 18 years. Thus, age is the only criterion to determine whether or not a patient is competent to provide consent for medical treatment.

In the Netherlands, adults are presumed to have the capacity to consent. Thus, when a minor reaches the legal age of majority (18 years), the capacity to consent is presumed. However, the Article 7:447 The New Dutch Law on Medical Services stipulates that: ${ }^{18}$

"A minor who has reached the age of sixteen years shall be competent to conclude a contract for medical services for himself, and to carry out legal acts directly connected with the contract."

Thus, the Dutch law stipulates that a minor who has reached the age of 16 years is capable of entering into a treatment agreement for his benefit, and to perform legal acts that are immediately related to the agreement. Therefore, based on the Dutch law, the fixed age of capacity to consent for medical treatment differs from the age of legal majority (18 years), it is set at 16 years. Thus, under a legally fixed age approach, minors are presumed to be competent to give consent for medical treatment.

What about in English Law? is the age of majority deemed as a criterion for determining whether the patient has the capacity to provide consent to medical treatment? In English Law, any person 18 years old or over will be able to give legally valid consent to the rendition of medical by a physician, so in health care matters, 18 years old enjoy as much autonomy as any other adult, ${ }^{19}$ however, because of the evolution in conceptions about individual human rights, the practical situation in health care is somewhat different from the formal legal position of the minor.

Sixty years ago, the issue of medical treatment of minors would never have been considered controversial. At that time, parental consent was required for almost any type of medical treatment, as it was required for any other situation involving children. Minors were simply not considered

\footnotetext{
${ }^{18}$ Ewoud Hondius and Annet Van Hooft, "The New Dutch Law on Medical Services", E-Journal on-line, <https:www.dspace.library.uu.nl> [accessed on 10/05/2020), p.10.

${ }^{19}$ Care Quality Commission "Brief guide: capacity and competence to consent in under 18s", <https://www.cqc.org.uk/sites/default/files/20180228_briefguide_capacity_consent_under_18s_v2.pdf>, [accesed on 5/03/2019], p.2.
} 
competent to make medical decisions. However, the past 60 years have witnessed a gradual expansion of the rights of minors, and health care has been no exception. Minors who previously had no medical rights now found themselves in the position of making decisions about the most intimate medical procedures. ${ }^{20}$

Therefore, in English Law young people aged 16 or 17 are presumed like adults as well to have the capacity to consent to medical treatment. Once children reach the age of 16 , they are presumed in law to be competent. In many respects, they should be treated as adults and can give consent for their own treatment, and refuse, including admission to hospital. Parents cannot override consent or refusal from a competent 16 or 17 year old. Neither can they consent on behalf of their competent 16 or 17-year old. ${ }^{21}$ Therefore, 16-17-years old can take medical decisions independently of their parents. The right of younger children to provide independent consent is proportionate to their competence..$^{22}$

In English Law, some courts have rejected chronological age as the sole criterion for determining whether the minor can effectively consent to treatment. The child's maturity, the nature of the procedure, and the benefit, if any, to the child are also considered in determining whether a minor's consent is effective to authorize treatment rendered, some courts have considered the age of the minor and his or her ability to comprehend the situation and make a reasoned decision as to treatment. Generally, whether a young person is sufficiently mature to provide valid consent to medical treatment depends not only on his or her age but also on whether he or she has sufficient maturity and intelligence to understand the nature and implications of the proposed procedure, surgery, examination or treatment. ${ }^{23}$ Where a child has "sufficient understanding and intelligence to enable him or her to understand fully what is proposed", that child is considered competent and is able to consent to medical procedures. ${ }^{24}$

Competence defines as the ability to understand information about the proposed treatment. This includes the treatment's purpose, nature, likely effects and risks, chances of success, and the availability of any alternatives. ${ }^{25}$ There is a difference between competence and capacity. Competence is a legal term, and it is generally understood to be the ability to perform actions needed to put decisions into effect. Competence is presumed unless it is determined by a court that the patient is not competent. Capacity is decision-specific. A problem may occur when competence

\footnotetext{
${ }^{20}$ Noel Merino (ed), Teen Rights and Freedoms Health Care, Greenhaven Publishing, New York: 2015, p.12.

${ }^{21}$ Care Quality Commission, Op.Cit. (note 23), p.4.

${ }^{22}$ Care Quality Commission, ibid., p.2.

${ }^{23}$ Malaysian Medical Council Guideline, Op.Cit. (Note 18), p.3.

${ }^{24}$ Kitipornchai, Leon and Then, Shih-Ning, "Cosmetic Surgery on Children: Professional and Legal Obligations in Australia" , Australian Family Physician,2011, E-Journal on-line,<https://search.informit.com.au/documentSummary;dn=180306558289488;res=IELHEA>, [accessed on 23/03/2019], p.51

${ }^{25}$ Mike Shaw, “Competence and Consent to treatment in children and adolescents", <https://www.gaysandstthomas.nhs.uk/resources/ education-training/sail/courses/review-ofconsent-capacity-younger people.pdf>, [accessed on 25/03/2019], p.151.
} 
and capacity are confused. We may talk about a person's 'lacking capacity', but in fact, that person may have the capacity to do all sorts of things, just not the thing we had in mind. When a lack of capacity becomes a feature of the person then we forget to look at capacity on a decision-bydecision basis. ${ }^{26}$

Criteria for testing the competency of a young person are as follows, ${ }^{27}$ The young person should be able to: understand simple terms, nature, purpose, and necessity for proposed treatment; Understand benefits/ risks/ alternatives and effect of non-treatment; Believe the information applies to them; Retain information long enough to make a choice; Make choice free from pressure. Furthermore, task-specific competence in relation to making healthcare decisions requires the fulfillment of standards, typified in the following definition: ${ }^{28}$ (i) The ability of the person to understand; (ii) The ability of the person to reason and deliberate; (iii) The ability of the person to communicate; (iv) The ability of the person to possess a set of values and goals; (v) The ability of the person to recognize options, and to appreciate the significance and meaning of different options.

Although in the field of medical services the term of competence is known both in the Indonesian Law and English Law. However in reality, in practice the term has a different meaning, so the application is different as well. What is interpreted as competence in English Law is not the same as what Indonesian Law interpreted? The difference in meaning certainly due to history, society, culture, habits, and events experienced differently. Competence to provide consent for medical treatment in Indonesia has the same meaning as the age of majority, while the competence to provide consent for medical treatment in English Law is the ability to comprehend the situation and make a reasoned decision as to treatment, or a patient has sufficient maturity and intelligence to understand the nature and implications of the proposed procedure, surgery, examination or treatment. Therefore, in English Law a minor can provide consent for medical treatment since The right of younger children to provide independent consent is proportionate to their competence, ${ }^{29}$ and because an age limit does not tell anything about the capability of judging a specific situation.

Base on the explanation above, then there is a different between Indonesian Law and English law. In English Law, the capacity of patient in providing consent to medical treatment is not only based on the age of majority criteria but also based on the patient competence. Therefore, the age of majority is not the only criterion that determines whether a patient has the capacity or not to provide consent to medical treatment, because competence is also used as a criterion of patient's

\footnotetext{
${ }^{26}$ Pia Matthews, Ethical Questions in Healthcare Chaplaincy, Learning to make informed Decision, Jessica Kingsley Publisher, London and Philadelpia: 2018, p.56.

${ }^{27}$ Russell Viner (ed), ABC of Adolescence, Blackwell Publisher, London: 2013, p.6.

${ }^{28}$ Bielby, P, "The conflation of competence and capacity in English medical law: A philosophical critique, Medicine, Health Care, and Philosophy", <http://e-resources.perpusnas.go.id:2130/10.1007/s11019-005-0537-z, 2005>, [ accessed on 25/03/2019 ], p. 357-69.

${ }^{29}$ Care Quality Commission," Op.cit. (Note 23), p.2.
} 
capacity to provide valid consent. Meanwhile in Indonesian law age of majority is the only criterion to determine a patient has the legal capacity or not to provide consent for medical treatment.

\section{Legal Consequences of Contract for Medical Treatment Made By A Minor}

The relationship between doctors and patients is generally a contractual relationship. There is a contractual agreement between the physician's relationship with the patient and the contractual relationship occurring in the civil law arrangements. The contractual relationship between the two parties is done legally to decide on a mutually agreed attitude. In conducting therapy there is a direct binding contract between physicians and patients. Patients want to be treated and doctors agree to treat. For a valid contractual agreement, there must be understanding and cooperation of the parties involved in the agreement. The doctor's relationship with the patient is a therapeutic relationship, which in the law is said to be an agreement to perform certain services. ${ }^{30}$

Article 39 Law Number 29 Year 2004 Regarding The Medical Practice state that:

"The medical practice is conducted Upon the agreement between doctor/dentist with the patient in the effort to maintain health, to prevent the disease, to improve someone's health, to cure the disease, and to recover someone's health."

Therefore, based on the provision above, the relationship between the doctor and the patient will be binding if previously there has been an agreement between the doctor and the patient. Thus the question is how can the parties make a legally valid consent for medical treatment? To answer this question, it must look at the legal terms of the consent as stipulated in Article 1320 of the Civil Code. Although Indonesian contract Law is still governed by book III of the Indonesian Civil Code inherited from the Colonial period, people are relatively comfortable with the existing legislation. ${ }^{31}$ Concerning the elements of a contract, In Indonesia, the elements of a contract are regulated in Book III of the Civil Code. Article 1320 of the Civil Code states that to establish a contract, four elements are required. (1) the consent of the parties; (2) a capacity to contract; (3) a subject certain; (4) a lawful purpose.

Based on Article 1320 of the Civil Code, a second element required in a contract is that the parties shall have the capacity to contract. Generally In Indonesia, any person has legal authority, however, there are groups of people who are considered incompetent in carrying out certain rights or obligations. Therefore, the legal subject of a person who basically has the legal authority is

\footnotetext{
${ }^{30}$ Harustiati A. Moein, "Informed Consent in Indonesia", <www.Liste.org/journals/index.php/JLPG/article>, [accessed on 20/04/2019], p.65.

${ }^{31}$ USA International Business Publications, Indonesian Privatization Programs and Regulations Handbook, Global Investment and Business Center, USA: 2013, p.166.
} 
someone who considered capable of acting alone and considered incapable of acting alone. Base on book III of Civil Code, in Indonesia, the incompetent people are divided into three groups, namely: (1). minors, (2) persons placed under guardianship, and (3) a married woman who is subject to the Civil Code.

Contracts concluded by either of these categories of persons can be annulled by a court of law, upon application of the incapable party or his lawful representative, provided the action is brought within five years of the termination of the incapacity. The obligation of the other party to the agreement is unaffected by incapacity unless and until the contract is annulled (voidable). Then, what is the legal consequences if the contract for medical treatment made by a minor? As mentioned above, that in Indonesia the incompetent people are minors (persons under 21 years of age) and persons placed under guardianship. Contracts made by either of these categories of persons can be annulled by a court of law. Thus, whatever the contract, if it made by minor then the legal consequences of a contract are voidable. Include a contract for medical treatment, when the contract for medical treatment made by a minor hence the contract are voidable.

How about in the Netherlands? There is the main rule for treating minors in the Netherlands. Based on age, minors are divided into three groups: ${ }^{32} \mathrm{i}$ ) younger than 12 years of age; ii) 12 years or older but younger than 16 ; iii) 16 years but younger than 18 years of age. Therefore, under the main rule, if a minor is 16 years old or older, the doctor closes the contract with the patient and the minor has to pay the bill, although at the end the parents will have to reimburse the minor as they have to pay for the upbringing of their child. As stipulates in article 7:447 paragraph 2 of the New Dutch Law on Medical Services which state that:

"The minor shall be liable for the fulfillment of any obligations resulting from the contract, without prejudice to his parent's obligation to bear the costs of care and upbringing." Thus, based on the Dutch Law, the contract for medical treatment made by a minor (16 years) a binding contract.

How about in English Law? A legal presumption exists that entitles anyone to enter into a contract unless an exception applies. One of those exceptions is in the case of a minor. Since 1969 the age of contractual capacity for individuals has been set at 18 and reaching the age of 18 is known as attaining majority. Minors are therefore those who have not attained the age of 18. English Law states that individuals who enter into a contract must have the capacity to enter into a contract, otherwise it is voidable. The age of majority person (Adults) who have full capacity are able to enter into contracts and enforce them at law (unless they are illegal contracts). The law sets out those

\footnotetext{
${ }^{32}$ Wolter Brands,at.all., "Limited Rights of Minors in Dutch Healthcare", E-Journal on-line, 2014, <https://www.ncbi.nlm.nih.gov/articles/ PMC5734816/>, [accessed on 10/05/2020].
} 
who do not have the legal capacity to contract particularly providing special legal protection to those who are minors, or under a mental disability. ${ }^{33}$

How about the minor, can minors enter into contractual agreements? In English Law a minor can enter into a contract at law, however, contracts with minors are roughly divisible into three classes: binding, voidable, and void.

1). Contract binding on the minor

Once the minor reaches the age of 18 , the contract becomes legally binding on both parties. Contracts binding on a minor are follows: a) Executed contracts for 'necessaries', i.e. goods and services necessary to maintain the minor in the style to which he is accustomed, having regard to his social position. Necessary goods are defined in the Sale of Goods act 1979 as goods suitable to his condition in life, and to his actual requirements at the time of sale and delivery. ${ }^{34} \mathrm{~A}$ married minor may be liable for necessaries supplied to his wife and children and for funeral and legal expenses, etc. b) Beneficial contracts of service, i.e. contracts of benefit to the minor in his education or training for a career, such as apprenticeships. Such contracts are binding even if they contain one or two burdensome terms, provided they are on the whole beneficial.

2). Contracts voidable by a minor

A voidable contract is a contract that can be ended. The contract is still valid, but it can be avoided by the minor who can legally terminate the agreement-before reaching the age of 18 years, or within a reasonable time of coming of age..$^{35}$

The courts may not uphold a contract if it is considered not to be the benefit of the minor. For example, in the case of De Francesco v Barnum (1889), a minor age 14 years old, entered into an agreement to train as a dancer on stage. However, the contract had conditions that were considered not beneficial to the minor and, therefore, the minor was not bound by the contract.

3). Contracts void against minors

The following are absolutely void against a minor: (i) Contracts for repayment of money lent or to be lent; (ii) Contracts for goods supplied or to be supplied (other than necessaries); (iii) all accounts stated, example IOUs and other admissions of indebtedness: Infants Relief Act 1874, s.1.

Relating to the contract for medical treatment, it leads us to the question can minor enter into contractual for medical treatment? The law states that individuals who enter into a contract must have the capacity to enter into a contract, otherwise it is voidable. Adults who have full

\footnotetext{
${ }^{33}$ Nicola Laver, “Capacity in Contract law", <https://www.inbrief.co.uk/contract-law/capacity-in-contract-law/>, [accessed on 25/3/2019], p.1.

${ }^{34}$ Cavendish Law Cards, Contract Law, second Edition, Cavendish Publishing Limited, London: 2000, p.119.

${ }^{35}$ Nicola Laver, Op.Cit. (Note 38), p.1.
} 
capacity are able to enter into contracts and enforce them at law (unless they are illegal contracts). ${ }^{36}$ Therefore, all parties must have the ability to understand the terms of and any obligations under the contract. Also, consent to the contract must be freely given (eg there cannot be any coercion/force, fraud, undue influence, or misrepresentation). ${ }^{37}$

As mentioned earlier, in English Law, minors are permitted to enter into contracts for limited purposes $^{38}$, the general law states that contracts entered into by children that are for necessaries are binding on children, as those for an apprenticeship, employment, and service where they are rightly said to be for the benefit of the child. Also generally necessaries are classed as food, clothing, shelter, education, and medical care. Since medical care is minor's necessary, therefore contract for medical care is a type of contract binding on a minor, hence this contract enforceable against the minor.

Based on the description above, the legal age limit for deeming a minor competent to consent vary widely among countries. Obviously, there is no international consensus on the exact age limit for presuming competence to consent in a minor.

\section{CONCLUSION}

There is a similarity between Indonesian law and Dutch law to determine whether a patient competent or not in giving consent to a contract for medical treatment that is based on age. Both Indonesian law and Dutch law use a legally fixed age approach to presume that minor competent in giving consent for medical treatment. However, based on Indonesian law, the fixed age of capacity to consent for medical treatment is set at a similar age of legal majority that is 18 years. Thus age is the only criterion to determine whether or not a patient competent to provide consent for medical treatment. However, in Netherland, based on Dutch law the fixed age of capacity to consent to contract for medical treatment differs from the age of legal majority, It is set at 16 years. Unlike Indonesia and Netherlands, English law uses a mixed approach in which fixed age limits are combined with competence. Therefore, the criterion for determining the capacity of a patient in giving consent to contract for medical treatment not only determine by a legally fixed age but also by the minor competence.

Furthermore, since medical care is considered as minor's necessary in English Law, therefore a contract for medical treatment enforceable and legally binding on the minor. It is similar to Netherland that any contract for medical treatment made by a minor (16 years) is legally binding. There is a contrast to Indonesian law that every contract made by a minor, includes the contract for

\footnotetext{
${ }^{36}$ Nicola Laver, ibid., p.1.

${ }^{37}$ Millie Johnson, "How to form a valid contract", < https:www.rocketlawyer.co.uk>, [accessed on 25/03/2019], p.1.

${ }^{38}$ Gillhams Solicitors, "Can Minors enter into contractual agreements?", <https://www.gillhams.com/>, [accessed on 25/03/2019].
} 
medical treatment is voidable.

Indeed, that age is an efficient indicator of competence that can measure easily and offers a clear framework. However, in fact, the age limit does not tell anything about the capability of judging a specific situation, because it could be there some individuals below the limit age of majority but more competent than adults. Thus for Indonesia, if remain to maintain that criteria for determining a competency of a patient to give consent to a contract for medical treatment based on the age of majority, it is better to imitate Dutch law which stipulates that the fixed age of capacity to consent to contract for medical treatment differs from the age of legal majority.

\section{REFERENCES}

\section{Books}

Cavendish Law Cards, Contract Law, second Edition, Cavendish Publishing Limited, London: 2000. Emily Jackson, Medical Law, OXFORD University Press, Second Edition New York: 2010.

Munir Fuady, Perbandingan Hukum Perdata, Citra Aditya Bakti, Bandung: 2005.

Noel Merino (ed), Teen Rights and Freedoms Health Care, Greenhaven Publishing, New York: 2015.

Pia Matthews, Ethical Questions in Healthcare Chaplaincy, Learning to make informed Decision, Jessica Kingsley Publisher, London and Philadelpia: 2018.

Russell Viner (ed), ABC of Adolescence, Blackwell Publisher, London: 2013.

USA International Business Publications, Indonesian Privatization Programs and Regulations Handbook, Global Investment and Business Center, USA: 2013.

Sri Warjiyati, Memahami dasar ilmu hukum: Konsep dasar ilmu hukum, edisi pertama, Prenadamedia Group, Jakarta: 2018.

\section{Journals}

Agustinus Danan Suka Dharma, "Keberagaman Pengaturan Batas Usia Dewasa Seseorang untuk Melakukan Perbuatan Hukum dalam Peraturan Perundang-Undangan di Indonesia", $<$ https://media.neliti.com/media/publications/213158-keberagaman-pengaturan-batas-usiadewasa.pdf>, [accessed on 25/03/2019].

Bielby, P, "The Conflation of Competence and Capacity in English Medical Law: A philosophical critique, Medicine, Health Care, and Philosophy", E-Journal on-Line, <http://eresources.perpusnas.go.id:2130/10.1007/s11019-005-0537-z, 2005>, [accessed on 25/03/2019].

Ewoud Hondius and Annet Van Hooft, "The New Dutch Law on Medical Services", E-Journal on-line, <https:www.dspace.library.uu.nl>, [accessed on 10/05/2020). 
Harustiati A. Moein, "Informed Consent in Indonesia", E-Journal on-Line, <www.Liste.org/journals/ index.php/JLPG/article>, [accessed on 20/04/2019].

Karine Senecal, at.all., "Legal Approaches Regarding Health-Care Decisions Involving Minors: Implications for Next-Generation Sequencing", 2016, E-Journal on-line, <https:www.ncbi.nlm.nih.gov/pmc/articles/PMC5110060/>, [accessed on 10/05/2020].

Kitipornchai, Leon and Then, Shih-Ning, "Cosmetic Surgery on Children: Professional and Legal Obligations in Australia", Australian Physician, 2011, E-Journal on-line, https://search.informit.com.au/documentSummary;dn=180306558289488;res=IELHEA, [accessed on 23/03/2019].

Nurkholis, "Penetapan Usia Dewasa Cakap Hukum Berdasarkan Undang-Undang dan Hukum Islam”, E-Journal on-Line, <Journal.stainkudus.ac.id/index.php/Yudisial/article/download/3223/ 2346>, [accessed on 25/03/2019].

Tengku Noor aziraTengkuZainudin, at.All., "The Meaning of a Valid Consent to Medical Treatment in Malaysia: Tan Ah Kau v Government of Malaysia Revisited.", E-Journal on-Line, $<w w w . p e r t a n i k a . u p m . e d u . m y>$, [accessed on 23/03/2019].

Wolter Brands, at.all., "Limited Rights of Minors in Dutch Healthcare", E-Journal on-line, 2014, <https://www.ncbi.nlm.nih.gov/articles/PMC5734816/>, [accessed on 10/05/2020].

\section{Laws and Regulations}

Civil Code.

Dutch Civil Code.

Law Number 29 of 2004 concerning Medical Practice.

Regulation of TheMinister of Health of The Republic of Indonesia Number 290/Menkes/PER/III/ Year 2008 Concerning Approval of Medical Action.

\section{Electronic Sources}

Care Quality Commission "Brief guide: capacity and competence to consent in under 18s", <https://www.cqc.org.uk/sites/default/files/20180228_briefguide_capacity_consent_under _18s_v2.pd>, [accesed on 5/03/2019].

Embassy kingdom of the Netherlands, "Protection of Minors",www.protection-of minors.eu/en/country/NL, [accessed on 20/05/2019].

Gillhams Solicitors, "Can Minors enter into contractual agreements?", $<$ https://www.gillhams.com/>, [accessed on 25/03/2019].

Irmadevita.com, "Batas UsiaDewasa”, https://irmadevita.com/2008/batas-usia-dewasa/, [accessed 
on $25 / 03 / 2019]$.

Malaysian Medical Council Guideline, "Consent for treatment of patients by registered medical practitioners", <medicalprac.moh.gov.my>, [accessed on 23/03/2019].

Mike Shaw, "Competence and Consent to treatment in children and adolescents", $<$ https://www.gaysandstthomas.nhs.uk/resources/education-training/sail/courses/reviewofconsent-capacity-younger-people.pdf>, [accessed on 25/03/2019].

Millie Johnson, "How to form a valid contract", < https:www.rocketlawyer.co.uk>, [accessed on 25/03/2019].

Nicola Laver, "Capacity in Contract law", <https://www.inbrief.co.uk/contract-law/capacity-incontract-law/>, [accessed on 25/3/2019].

NN, “Capacity Law Lecture, extract from JC Smith, Smith \&Thomas:A Casebook on Contract, Eleventh Edition", 2000, chapter 17 , <https://www.lawteacher.net/lecture-notes/capacitylecture.php>, [accessed on 25/03/2019].

Wahyono Darmabrata, "Usia Dewasa Undang-Undang No. 1 Tahun 1974 Tentang Perkawinan", <file:///c:/Documents\%20\%settings/User/My\%Documents/Downloads/1406-2740-1SM\%20(1).pdf>, [accessed on 25/03/2019]. 